\title{
Technology Based Assessment of Cross Cultural Training with The Expatriate's Performance using Structural Equation Model
}

\author{
V. Sathya Moorthi, S. B. Inayath Ahamed, K. Ravindran
}

\begin{abstract}
In order to meet the global demand and face the international competition it has become inevitable for the MNCs to send employees overseas and accomplish the targets. But one of the most important problems that MNCs are troubled with is that of expatriate failure and premature arrival. It is estimated that around 10 to 80 percent of the expatriates sent abroad return back home early. The main reason behind premature return happens to be the cultural diversity and the associated problems faced by the expatriate employees in the host country. Also the lack of proper training to adjust to the changed surroundings makes the employees return back quickly. The expatriate managers face many difficulties and challenges in different forms. They can handle these difficulties only when they are properly prepared for the same through sound cross cultural training. The study includes the qualitative in depth interview with a specific pattern of questionnaire approaching both the employees and their supervisors to understand the effectiveness of cross-cultural training programs on the performance and adjustment levels of the expatriates in the host country. It also focuses on the approaches in the cross-cultural training programs and on the skills needed for effective cross-cultural communication.
\end{abstract}

Keywords: cross cultural training,expatriate, factors, impact, organizational performance.

\section{INTRODUCTION}

Due to increased implication and practice of globalization through free trade agreements, the rapid expansion of global markets has led to the growth and expansion of MNCs resulting in human capital movement across nations. Expatriates are employees who are hired or transferred to work on assignments in an overseas nation to meet the company objectives. In order to be globally fit in the competition, MNCs are on a hunt to find the right and appropriate personnel who can work for their business overseas. But there being diversified work culture and social tendencies around the globe, it becomes difficult for individuals to adjust and adapt to different circumstances around them hence it becomes important and essential for the organizations to provide them with cross-cultural training so that prompt performance can be delivered and results can beachieved.

Revised Manuscript Received on December 15, 2019.

Mr. V. SathyaMoorthi*, Research Scholar, Department of Business Krishnan Koil, sathyamoorthi.v@klu.ac.in.

Dr. S. B. InayathAhamed, Assistant Professor, Department of Business Administration, Kalasalingam Academy of Research and Education, Krishnan Koil, inayathahamed@klu.ac.in

Dr. K. Ravindran, Assistant Professor, Department of Business Administration, Kalasalingam Academy of Research and Education, Krishnan Koil, ravindran.k@klu.ac.in Administration, Kalasalingam Academy of Research and Education,

Since the expenditure incurred on sending an employee on international assignments are estimated to be high, the first year cost itself is calculated to be three times the employee's domestic annual salary hence a company usually expects a high level of performance to be

Delivered (Shaffer, Harrison \& Gilley,1999). There are shreds of evidence that prove the fact that most of the MNCs do not deliver any type of cross-cultural training neither before departure or after the arrival of the employees from foreign assignments. For most of the companies that provide training which only consists of a short informal briefing given before departure which is insufficient and inappropriate (Pusch 2003, pp 21-22). Most of the multinational companies fail to recognize and understand the importance of cross-cultural training and as a result, the assignments fail. Usually, the expatriates manage and organize themselves without any such training or support. It is the duty of every organization to understand the need and necessity of cross-cultural training and provide the expatriates with sufficient and essential training which enables them to quickly adapt and adjust to the new and alien environment around them and accordingly focus on their work and meet up the targets as assigned tothem.

Cross cultural training benefits not only the expatriates but also the host country employees and managers as well as apart from culture there are other aspects like working style, interactions that also differ from country to country and training happens to be the bond that brings these diversified nations on one common notion by imbibing adjustment and adaptability into the employees. It is easy for employer to say and ask the employees to "Be Roman in Rome" and expect results from the expatriates which leads to a huge lot of misunderstandings and uneasy workingrelationships.

Cross-cultural training has been broadly divided four areas, the first being cognitive approach here the skills and learning has been inculcated through medium of lecture, the second one being affective approach where training and learning is imbibed in such a manner that the employees develop affective response which will create cultural insights in the trainee. The next approach being experiential and as the name suggests it makes learning through recreation of realistic scenario and simulation activities and the fourth one being language training where the language of the host country is taught as language happens to be the foremost important criteria for adjusting in a new place. Other than the above four areas there may various other areas where the expatriates can be trained as well like attribution training, interaction training, didactic training, cultural awareness trainingetc. 
The main reason for the failure of expatriate and their premature arrival happens to be working in a culturally diversified and different country with no knowledge about their language and culture which creates difficulty in adjusting and delivering results and performance as expected (Briscoe \& Schuler;2004; Dowling \& Welch,2005). Henceforth knowing about different cultures and having expertise in cross-cultural communication has become a must for the expatriates. Aware of this fact a large number of MNCs endeavor to equip their expatriates with the required and the proper training needed (Ashamalla 1998; Caliguari, Phillips, Lazarova, Tarique\&Burgi;2001). MNCs usually operate in a culturally diversified environment. So cultural adaptation becomes an issue of basic concern for the expatriates both in the domestic and the host country also.Culture is the root for an individuals existence, Culture defines a human being and also influences every small act that one does at all times and in all places (Boakeri 2004). The more the expatriate knows, studies and understands the host country where he is about to go the greater the are the chances of successful job performance.

1. To understand the importance and role of cross- cultural training on expatriatesperformance.

2. Determine how cross-cultural training is actually implemented and provided to theexpatriates.

3. To ensure that the requirements of expatriates are fulfilled through cross-culturaltraining.

4. To understand the variants of training given to the expatriates under cross culturaltraining.

\section{LITERATUREREVIEW}

Employees have always been the cause behind both the success and failure of any organization and its commitments. Hence it becomes the prime responsibility of the organization to ensure that its employees are up to date with the required information and knowledge that they need for accomplishing their targets on time. Here in this study, we will be discussing the expatriates that are the employees sent on a temporary basis for overseas assignments and their training requirements needed to adjust to the cultural changes that the expatriates experience during their course of stay in the host country. Hence the cross-cultural training presumes a lot of importance for all growing MNCs and should be undertaken by the organization with great care and caution as it is the training and its effectiveness that decides success or failure of the overseas assignments. Here we begin the review of the literature with a brief discussion of the opinions laid out by differentexperts.

Black (1988) opines that working in a different country requires adjustment and adaptation to several aspects. He points out three variables of expatriate manager adjustment (i) work adjustment includes the duties and professional accomplishments that the expatriate needs to perform. (ii) Relational adjustment is about how he interacts, deals and maintains relations with the people of the host nation and finally (iii) general adjustment which speaks about the social life in the host country. These variables are related to the employee, company and contextual factors. The variables associated with the individual identify the individual's capacity to adjust to the new country and the situations prevailing there, while

contextual factors are related to the amount of time spent in the host country and the personal and professional support

that the expatriate gets during the period. Company related variable refers to the support that the parent company extends and the corporate cultural differences that exist between the host nation subsidiary and the home nation parent company and the cross cultural training that is provided to resolve the same.

Mcenery and Desharnis(1990) stated that the cultural change leads to a state of shock resulting in mental stress due to the changes in the culture that is observed around. Due to sudden differences posing difficulty in cultural adaptation due to the different culture variation around them the expatriates tend to feel lonely and homesick. They start comparing their culture with that of the host country and find it difficult to adjust to the disparities spotted by them. This process of assessing and accepting the new changes resulting from cultural diversities of a different nation can be called as cross-culturaladjustment.

Shah (2011) in her study based on the preparation and training support provided to the IT professionals of Indian IT MNCs sent to Australia conducted an interview with 54 IT expatriates from 5 IT MNCs in Australia and observed that the main difference between Indian IT MNCs and western IT MNCs is that the expatriates from western IT MNCs are going to their subsidiary office where they have the required support system available. While the Indian IT expatriates prefer going to an all together new organization where the required support may not be available. She further noted that such cross cultural support can be easily extended through the organizationalsupport.

Family happens to be the most important component for any expatriate to adjust to the new cultural changes that he faces in the host country. Only a few studies have focused on this variable. Tung(1981) in her study "Selection and training of personnel for overseas assignments" had researched 300 firms operating abroad to understand the role of family on the expatriates adaptation process. It was found that nearly $40 \%$ of the companies had interviewed the employees spouse during the pre departure preparation. It was also found that the major difficulty was faced by the expatriates spouse to adjust to the new cultural surroundings which actually ended up being the main reason for failed overseas assignments.

For a while cross cultural training has been detailed as a crucial source to ensure the competencies required being processed by expatriates managers in order to successfully perform and achieve the targets assigned (Tung 1981;Brislin,1981;Scullion \& Collins,2006). The main the aspect of cross cultural training is as to what extent it makes a difference in the output and performance by enhancing the skills and knowledge of the expatriates and their ability to adjust to a unfamiliar culture. Cross cultural training actually focuses on interactions of working and getting together with people from a different culturalbackground.

\section{METHODOLOGY}

Each number one and secondary statistics used for the examine. Number one statistics were accrued through the questionnaire. 
Secondary data became taken from posted resources like journals, internet, books, and articles; evaluation has been made on the idea of reaction received from therespondents

The research type involves Descriptive. 783 respondents were selected at $95 \%$ confidence level and $0.035 \%$ of margin of error. The data have been collected by using the structured questionnaire with a probability resign of simple random sampling.

\section{RESULTS}

The respondents were asked to explicit their opinion on a 5factor Likert scale. The scores had been assigned as strongly agree (five factors) to strongly disagree (1 point). The preliminary evaluation changed into made using descriptiveevaluation.

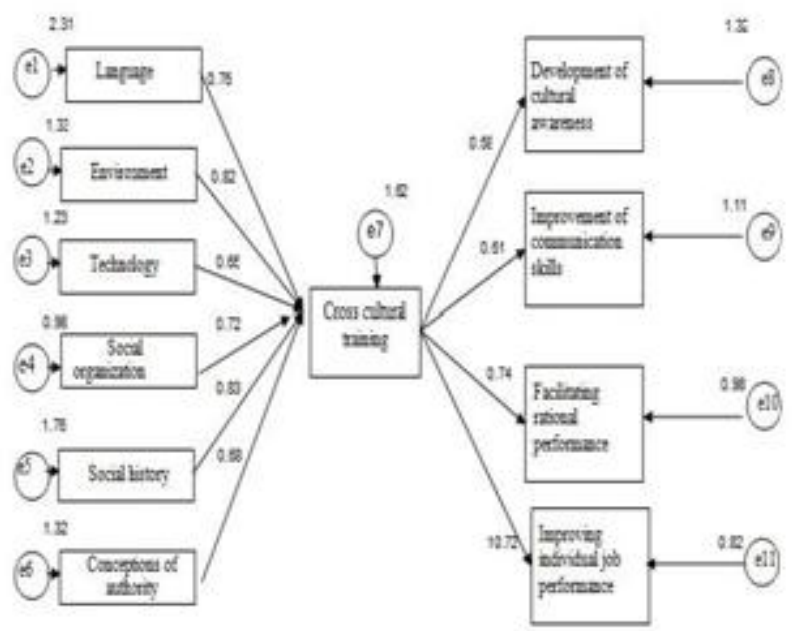

Figure 1:Structural model - standardized regression weight Factor loadings

This assessment estimates the standardized loadings of the various latent variables and observed variables as indicators of the constructs. This SEM diagram shows the relationships between all the endogenous and exogenous constructs are highlysignificant.

Table 1: Structural model - Covariance relationship estimate

\begin{tabular}{|c|c|c|c|c|c|}
\hline \multicolumn{3}{|c|}{ Covariance relationship estimate } & \multirow{2}{*}{$\begin{array}{r}\begin{array}{r}\text { Beta } \\
\text { estimate }\end{array} \\
0.76\end{array}$} & \multirow{2}{*}{$\begin{array}{c}\text { C.R } \\
. \\
9.558\end{array}$} & \multirow{2}{*}{$\begin{array}{r}\mathrm{P} \\
* * *\end{array}$} \\
\hline Language & $\begin{array}{l}-- \\
- \\
>\end{array}$ & $\begin{array}{l}\text { Cross cultural } \\
\text { training }\end{array}$ & & & \\
\hline Environment & $\begin{array}{l}-- \\
- \\
>\end{array}$ & $\begin{array}{l}\text { Cross cultural } \\
\text { training }\end{array}$ & 0.82 & 11.404 & $* * *$ \\
\hline Technology & $\begin{array}{l}-- \\
- \\
>\end{array}$ & $\begin{array}{l}\text { Cross cultural } \\
\text { training }\end{array}$ & 0.65 & 5.595 & 0.042 \\
\hline $\begin{array}{c}\text { Social } \\
\text { organization }\end{array}$ & $\begin{array}{l}-- \\
- \\
>\end{array}$ & $\begin{array}{l}\text { Cross cultural } \\
\text { training }\end{array}$ & 0.72 & 6.728 & $* * *$ \\
\hline Social history & $\begin{array}{l}-- \\
- \\
>\end{array}$ & $\begin{array}{l}\text { Cross cultural } \\
\text { training }\end{array}$ & 0.83 & 3.268 & 0.038 \\
\hline $\begin{array}{l}\text { Conceptions } \\
\text { of authority }\end{array}$ & $\begin{array}{l}-- \\
-\end{array}$ & $\begin{array}{l}\text { Cross cultural } \\
\text { training }\end{array}$ & 0.68 & 13.404 & 0.043 \\
\hline \multirow{2}{*}{$\begin{array}{l}\text { Cross } \\
\text { cultural } \\
\text { training }\end{array}$} & & \multirow{2}{*}{$\begin{array}{l}\text { Development } \\
\text { of cultural } \\
\text { awareness }\end{array}$} & & & \\
\hline & $\begin{array}{l}-- \\
- \\
>\end{array}$ & & 0.58 & 10.404 & 0.043 \\
\hline
\end{tabular}

\begin{tabular}{|c|c|c|c|c|c|}
\hline \multirow{2}{*}{$\begin{array}{c}\text { Cross } \\
\text { cultural }\end{array}$} & $\begin{array}{c}-- \\
-\end{array}$ & Improvement & 0.61 & 11.595 & 0.032 \\
\hline \multicolumn{2}{|c|}{ Covariance relationship estimate } & $\begin{array}{c}\text { Beta } \\
\text { estimate }\end{array}$ & C.R. & $\mathrm{P}$ \\
\hline \multirow{2}{*}{ training } & & $\begin{array}{c}\text { of } \\
\text { communication }\end{array}$ & & & \\
\cline { 2 - 5 } & skills & Facilitating & & & \\
\cline { 2 - 6 } $\begin{array}{c}\text { Cross } \\
\text { cultural } \\
\text { training }\end{array}$ & -- & $\begin{array}{c}\text { rational } \\
\text { performance }\end{array}$ & 0.74 & 5.728 & $* * *$ \\
\hline \multirow{2}{*}{$\begin{array}{c}\text { Cross } \\
\text { cultural } \\
\text { training }\end{array}$} & -- & $\begin{array}{c}\text { Improving } \\
\text { individual job } \\
\text { performance }\end{array}$ & 0.72 & 4.268 & $* * *$ \\
\hline
\end{tabular}

Structural diagram of the analysis presented in Figure 1, depicts the standardized model based on the six latent variables, Language,Environment, Technology, Social organization, Social history and Conceptions of authority shows the relationship between the factors affecting cross cultural training and cross cultural training. Table 1 represents the results of the Covariance relationship estimate among the latent variables, dependent variable and mediating variable. The critical value, which is more than 1.96, is considered to be significant (David Garson,2016).

The critical value of latent variables, Language (9.558),Environment (11.404), Technology (5.595),Social organization (6.728),Social history (3.268) and Conceptions of authority (13.404) have a positive impact with Cross Cultural training. Cross cultural training have a positive impact with Development of cultural awareness(10.404),Improvement of communication skills(11.595),Facilitating rational performance (5.728) and improving individual jobperformance(4.268).

\section{CONCLUSION}

Effective cross cultural training ensures the success of the overseas assignment through expatriates. It increases their knowledge and skill, motivates them to foresee the personal and professional benefits of cultural diversities and cross cultural competencies. At the organizational level cultural competencies can be put together with policy requirements and service delivery objectives to be achieved at the first priority basis. At professional front cultural competencies can be combined with the standards and benchmarks that are used to measure the performance of employees in an organization. At the individual level cross cultural training assumes importance when it meets the requirements and benefits of the employees in several ways. Motivating employees with incentives and opportunities on the grounds of cultural competencies can also help to imbibe it as a part of their professional achievement.

Since expatriate success is crucial for a company so is training them equally important. The study tries to explain the same and the impact of cross cultural training on the expatriate's performance. 


\section{REFERENCES}

1. Pusch, M. D. 2003. "Cross-cultural training in organizationalcontexts",inLandis,D.,\&Bennet,

2. J. \&Bennet, M. J. (Eds.), Handbook of intercultural training, Thousand Oaks, CA: Sage Publications.

3. Shaffer, M. A., Harrison, D. A. \& Gilley, K. M. 1999. "Dimensions, Determinants, and Differences in the Expatriate Adjustment Process", Journal of International Business Studies, Vol. 30, No. 3, pp. 557-581

4. Briscoe, Dennis \& Schuler, Randall. (2004). International human resource management (2nd ed.). London:Routledge

5. Ashamalla, Maali. (1998). International human resources management practice: The challenge of expatriation. Commercial Reviews, 8(2),54-65

6. Black, J. (1988). Work role transitions: A study of American expatriatemanagers inJapan.

7. Journal of International Business Studies, 19, 277- 294

8. Boakari, Francis Musa. (2004). Study abroad could begin at university. LOGOS Newspaper, 105(4), p. 6.

9. Dowling, Peter \& Welch, Denice. (2005). International human resource management: Managing people in an international context (4th ed.). Mason, OH:South-Western

10. Tung, R. (1981). Selection and training of personnel for overseas assignments. Columbia Journal of World Business, 68-78.

11. Shah, D. (2011). Indian Information Technology Expatriates on an International Assignment: Impact of Pre-Departure Preparation on InitialAdjustment.

12. Brislin, R. W. (1981). Cross-cultural encounters: Face-to-face interaction. Allyn \&Bacon.

13. Scullion, Hugh \&Collings, David. (2006). International recruitment and selection. In Hugh Scullion \& David G. Collings (Eds.), Global staffing (pp. 68-86). London \& New York: Routledge.

\section{AUTHORS PROFILE}

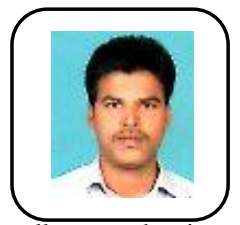

V. Sathya Moorthi, Completed graduation B.Sc., in special maths in The American College, Madurai and post Graduate MBA in Kalasalingam University, Currently a research scholar in kalasalingam university in the department of management. I have 2 years of research experience and 7 years of teaching experience from various colleges and university. I have specialized $\mathrm{n}$ human resource management and marketing.

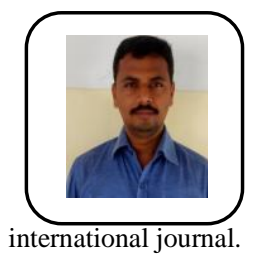

Dr. K. Ravindran, Completed graduation BA Economics in ChikkaiyaNaickar Collage and post graduation MBA in Periyar University. Recently he has completed his Doctorate in periya university specialized in Marketing. He posses 2 years of industry experience and 8 years of teaching experience. $\mathrm{He}$ has published 2 papers in

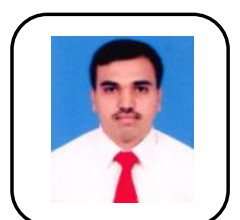

Dr. S. B. Inayath Ahamed, Completed graduation $\mathrm{BE}$ (EEE) in Sona College of Technology and post graduation MBA in BS Rahuman University. He has completed his Doctorate in periya university specialized in Marketing. He posses 3 years of teaching experience. He has published 17 papers in various national and international journal. 